\title{
Combined Catalysis for Engineering Bioinspired, Lignin-Based, Long-Lasting, Adhesive, Self-Mending, Antimicrobial Hydrogels
}

Samson Afewerki, ${ }^{*}$ Xichi Wang, Guillermo U. Ruiz-Esparza, Cheuk-Wai Tai, Xueying Kong,

Shengyang Zhou, Ken Welch, Ping Huang, Rhodel Bengtsson, Chao Xu, ${ }^{*}$ and Maria Strømme*

\section{Supporting Information}

Supplementary Table 
Table S1. Screening studies for engineering the lignin-based, crosslinked, tissue adhesive hydrogels, investigating various parameters such as metal salts and concentrations.

\begin{tabular}{|c|c|c|c|c|c|c|c|}
\hline Entry[a] & Polymer[b] & $\begin{array}{l}\mathrm{H}_{2} \mathrm{O} \\
(\mathrm{mL})\end{array}$ & $\begin{array}{l}\text { Metal salt } \\
(0.5 \mathrm{~mL})^{[\mathrm{c}]}\end{array}$ & $\begin{array}{c}\text { APS } \\
\text { (1 wt. } \%)\end{array}$ & $\begin{array}{l}\text { Lignin metal } \\
\text { NPs }(m L)\end{array}$ & $\begin{array}{l}\text { Crosslinked } \\
\text { hydrogel }^{[d]}\end{array}$ & $\begin{array}{c}\text { Tissue } \\
\text { adhesive }^{(e)}\end{array}$ \\
\hline 1 & PAA & 1.0 & $\mathrm{Pd}(\mathrm{OAc})_{2}$ & $0.5 \mathrm{~mL}$ & & No & - \\
\hline 2 & PAA & 0.5 & $\mathrm{AgNO}_{3}$ & $0.5 \mathrm{~mL}$ & $\begin{array}{l}\text { Lignin Pd- } \\
\text { NPs }(0.5)\end{array}$ & No & - \\
\hline 3 & PAA & 1.0 & & $0.5 \mathrm{~mL}$ & $\begin{array}{l}\text { Lignin Pd- } \\
\text { NPs }(0.5)\end{array}$ & Yes & Yes \\
\hline 4 & PAA & 0.5 & & $0.5 \mathrm{~mL}$ & $\begin{array}{l}\text { Lignin Pd- } \\
\text { NPs (1.0) }\end{array}$ & Yes & Yes \\
\hline 5 & PAA & 1.0 & $\begin{array}{c}\mathrm{Cu}\left(\mathrm{NO}_{3}\right) \cdot \\
2.5 \mathrm{H}_{2} \mathrm{O}\end{array}$ & $0.5 \mathrm{~mL}$ & & No & - \\
\hline 6 & PAA & & $\mathrm{AgNO}_{3}$ & $0.5 \mathrm{~mL}$ & $\begin{array}{l}\text { Lignin Cu- } \\
\text { NPs (1.0) }\end{array}$ & No & - \\
\hline 7 & PAA & 1.0 & & $0.5 \mathrm{~mL}$ & $\begin{array}{l}\text { Lignin Cu- } \\
\text { NPs (0.5) }\end{array}$ & Yes & Yes \\
\hline 8 & PAA & 0.5 & & $0.5 \mathrm{~mL}$ & $\begin{array}{l}\text { Lignin Cu- } \\
\text { NPs (1.0) }\end{array}$ & Yes & Yes \\
\hline 9 & PAA & 1.0 & $\begin{array}{c}\mathrm{Fe}\left(\mathrm{ClO}_{4}\right)_{3} . \\
\mathrm{xH}_{2} \mathrm{O}\end{array}$ & $0.5 \mathrm{~mL}$ & & No & - \\
\hline 10 & PAA & & $\mathrm{AgNO}_{3}$ & $0.5 \mathrm{~mL}$ & $\begin{array}{l}\text { Lignin Fe- } \\
\text { NPs (1.0) }\end{array}$ & No & - \\
\hline 11 & PAA & 1.0 & & $0.5 \mathrm{~mL}$ & $\begin{array}{l}\text { Lignin Fe- } \\
\text { NPs }(0.5)\end{array}$ & Yes & Yes \\
\hline 12 & PAA & 0.5 & & $0.5 \mathrm{~mL}$ & $\begin{array}{l}\text { Lignin Fe- } \\
\text { NPs (1.0) }\end{array}$ & Yes & Yes \\
\hline 13 & PAA & 1.0 & $\begin{array}{c}\mathrm{Ni}\left(\mathrm{NO}_{3}\right) \\
6 \mathrm{H}_{2} \mathrm{O}\end{array}$ & $0.5 \mathrm{~mL}$ & & No & - \\
\hline 14 & PAA & & $\mathrm{AgNO}_{3}$ & $0.5 \mathrm{~mL}$ & $\begin{array}{l}\text { Lignin } \mathrm{Ni}- \\
\text { NPs }(1.0)\end{array}$ & No & - \\
\hline 15 & PAA & 1.0 & & $0.5 \mathrm{~mL}$ & $\begin{array}{l}\text { Lignin Ni- } \\
\text { NPs }(0.5)\end{array}$ & Yes & Yes \\
\hline 16 & PAA & 0.5 & & $0.5 \mathrm{~mL}$ & $\begin{array}{l}\text { Lignin Ni- } \\
\text { NPs (1.0) }\end{array}$ & Yes & Yes \\
\hline 17 & PAA & 1.0 & $\begin{array}{c}\mathrm{Zn}\left(\mathrm{NO}_{3}\right) \\
6 \mathrm{H}_{2} \mathrm{O}\end{array}$ & $0.5 \mathrm{~mL}$ & & No & - \\
\hline 18 & PAA & & $\mathrm{AgNO}_{3}$ & $0.5 \mathrm{~mL}$ & $\begin{array}{l}\text { Lignin Zn- } \\
\text { NPs (1.0) }\end{array}$ & No & - \\
\hline 19 & PAA & 1.0 & & $0.5 \mathrm{~mL}$ & $\begin{array}{l}\text { Lignin Zn- } \\
\text { NPs }(0.5)\end{array}$ & Yes & Yes \\
\hline 20 & PAA & 0.5 & & $0.5 \mathrm{~mL}$ & $\begin{array}{l}\text { Lignin Zn- } \\
\text { NPs (1.0) }\end{array}$ & Yes & Yes \\
\hline 21 & PAA & & $\mathrm{AgNO}_{3}$ & $0.5 \mathrm{~mL}$ & $\begin{array}{l}\text { Lignin Zn- } \\
\text { NPs (1.0) }\end{array}$ & No & - \\
\hline
\end{tabular}

[a]Reaction conditions: the polymer (20 wt.\%) was mixed into water and/or Lignin metal NPs solution and APS ( $0.5 \mathrm{~mL}, 1 \mathrm{wt} . \%$ ) was added (for some entries, metal salts ( $0.5 \mathrm{~mL}, 1 \mathrm{wt} . \%)$ were also added), followed by incubation at room temperature for 1-16 h. The total amount of solvent was $2 \mathrm{~mL}$ for all entries. [b] $20 \mathrm{wt} . \%$ of the polymers was prepared to give a final concentration of $10 \mathrm{wt} . \%$. [c]1.0 wt.\% of the metal salts was prepared. [d]The success of the crosslinking was assessed by the formation of a self-standing hydrogel. [e]The initial assessment of the tissue adhesive properties in the screening study was carried out by the finger of the researcher being placed onto the crosslinked hydrogel and then lifted. APS = ammonium persulfate; NPs = nanoparticles; PAA = polyacrylic acid. 


\section{Supplementary Schemes}

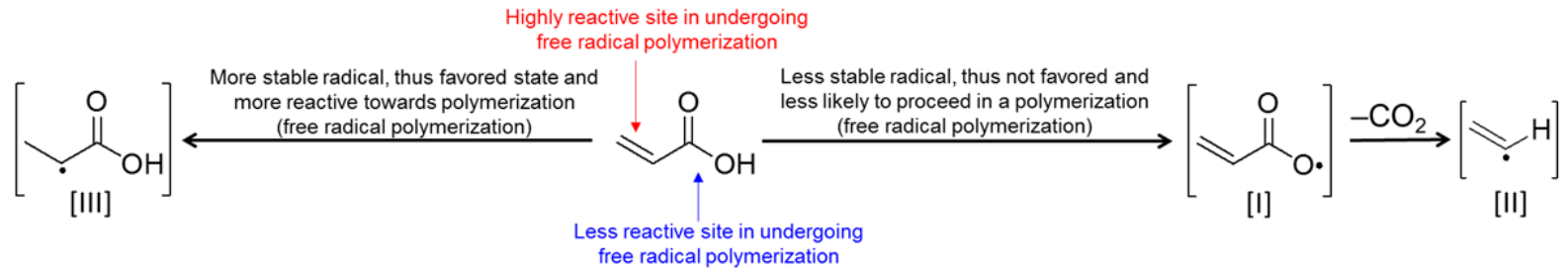

Scheme S1. The possible radicals generated from acrylic acid (AA) when treated with the radical initiator ammonium persulfate (APS). ${ }^{1}$

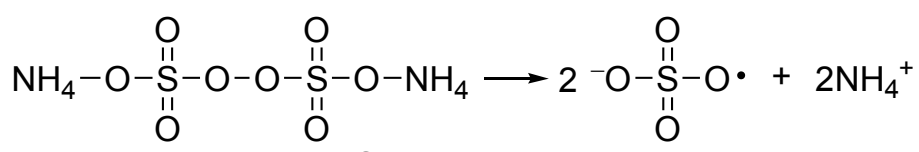

Radical initiator: APS
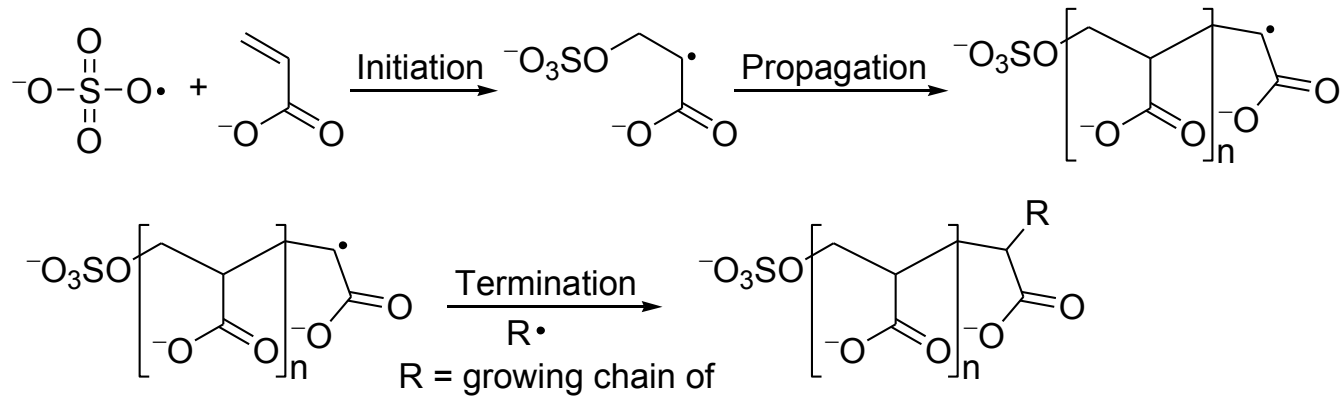

PAA radical or persulfate radical

Scheme S2. The mechanism of the free radical polymerization of AA monomers into PAA in the presence of the radical initiator APS..$^{2,3}$

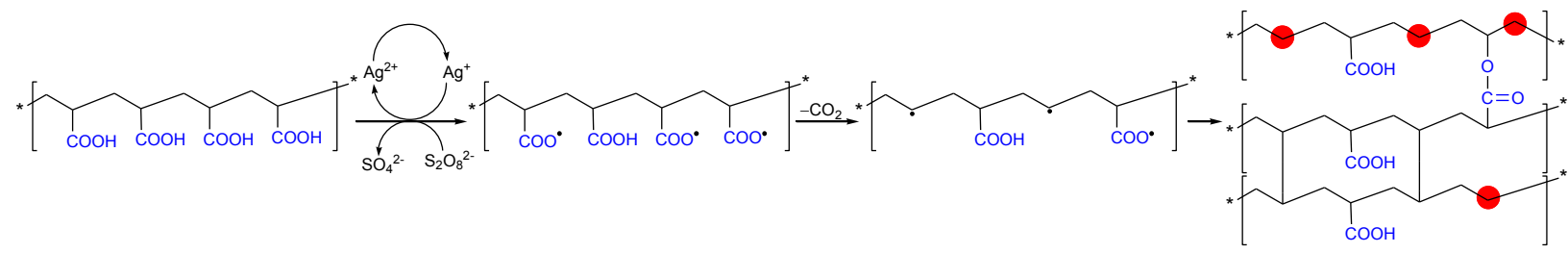

Scheme S3. The mechanism of the Ag-catalyzed oxidative decarboxylation reaction leading to intermolecular crosslinking of polyacrylic acid (PAA) polymer. ${ }^{4}$ 


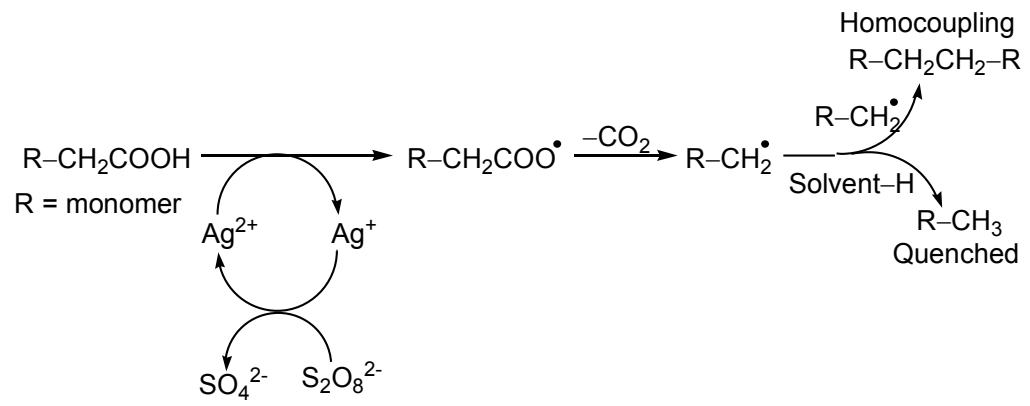

Scheme S4. The mechanism of the decarboxylation reaction of carboxylic $(\mathrm{COOH})$ containing monomers such as AA. 5,6

\section{Supplementary Figures}
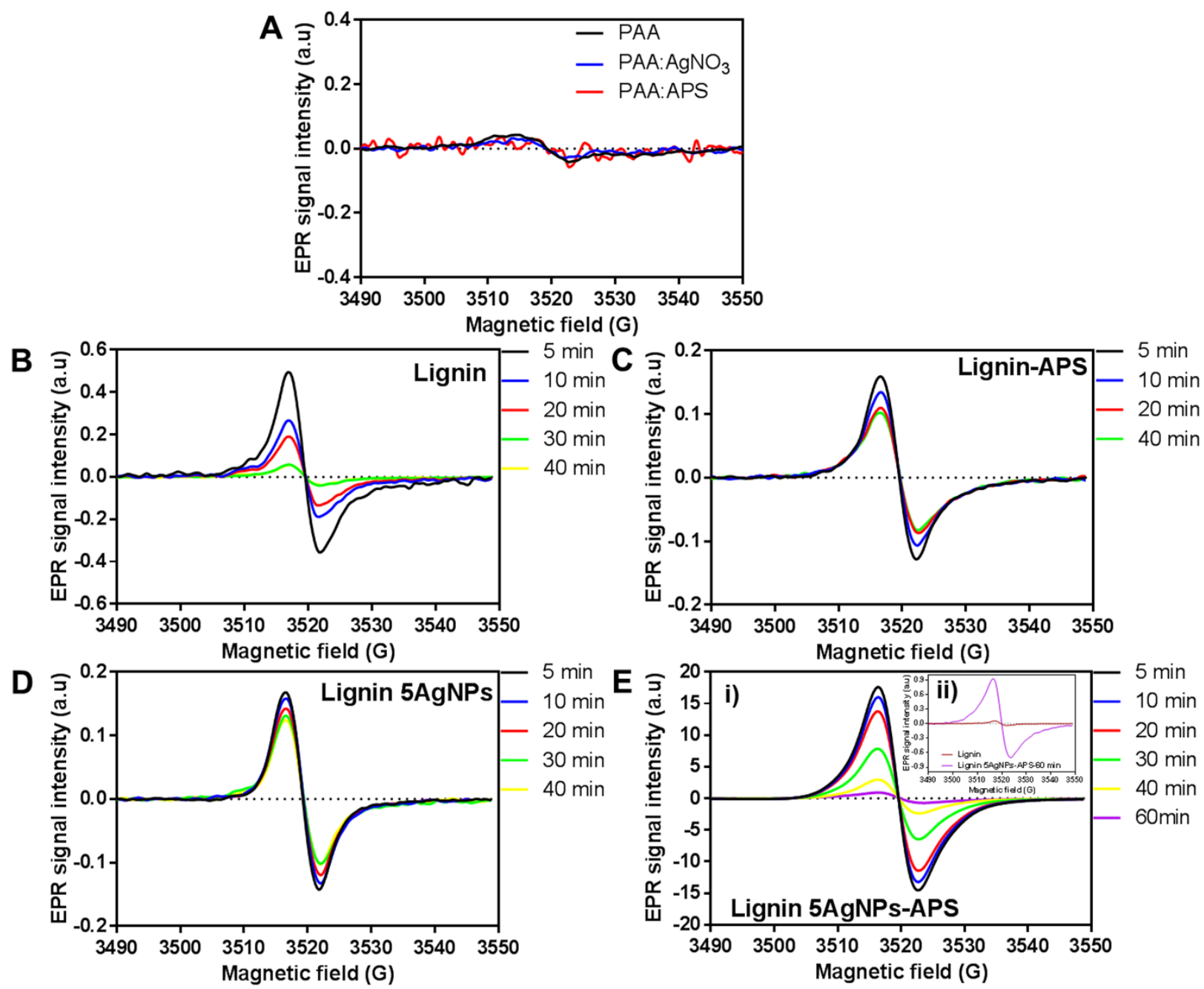

Figure S1. Electron paramagnetic resonance (EPR) evaluation of the various reactions and components. (A) The EPR spectra of PAA, PAA combined with $\mathrm{AgNO}_{3}$ and PAA merged with APS. (B) 
The spectra of lignin at various timepoints. (C) Lignin combined with APS. (D) The EPR spectra of the Lignin 5AgNPs at various timepoints. (E) i) The EPR spectra of the Lignin 5AgNPs combined with APS at various timepoints, demonstrating the long-lasting and regenerative redox environment in the material. ii) The insert shows the spectrum after 60 min compared to the spectrum of lignin. APS = ammonium persulfate; NPs = nanoparticles; PAA = polyacrylic acid.

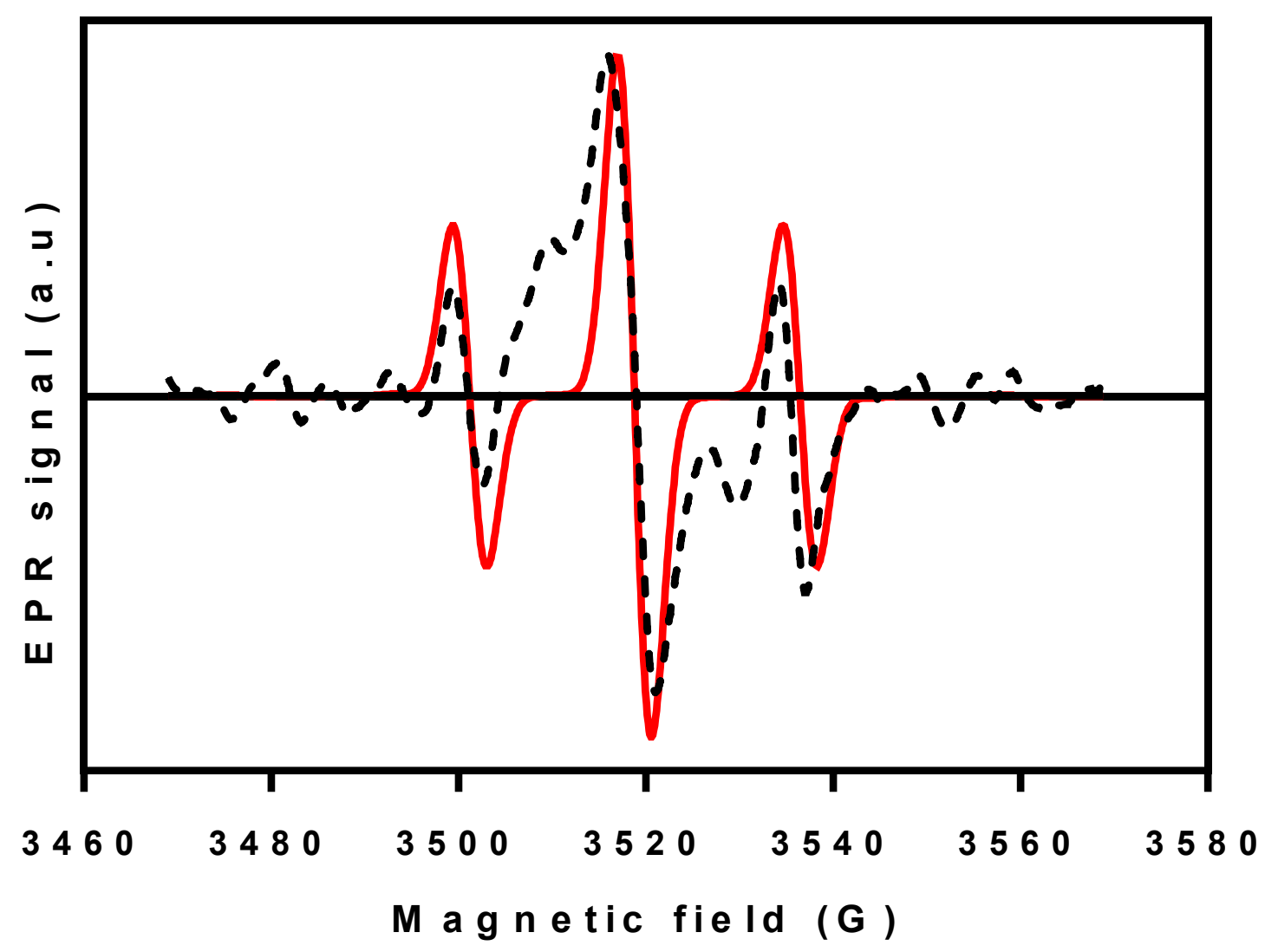

Figure S2. The EPR spectra recorded and simulated to confirm the presence of the radical ${ }^{\circ} \mathrm{CH}_{2}$ species. The black dashed line is the spectrum recorded for the solution $10 \mathrm{~min}$ after the reaction was initiated. The red spectrum is the EPR simulated spectrum for a ${ }^{\circ} \mathrm{CH}_{2}$ radical species. 

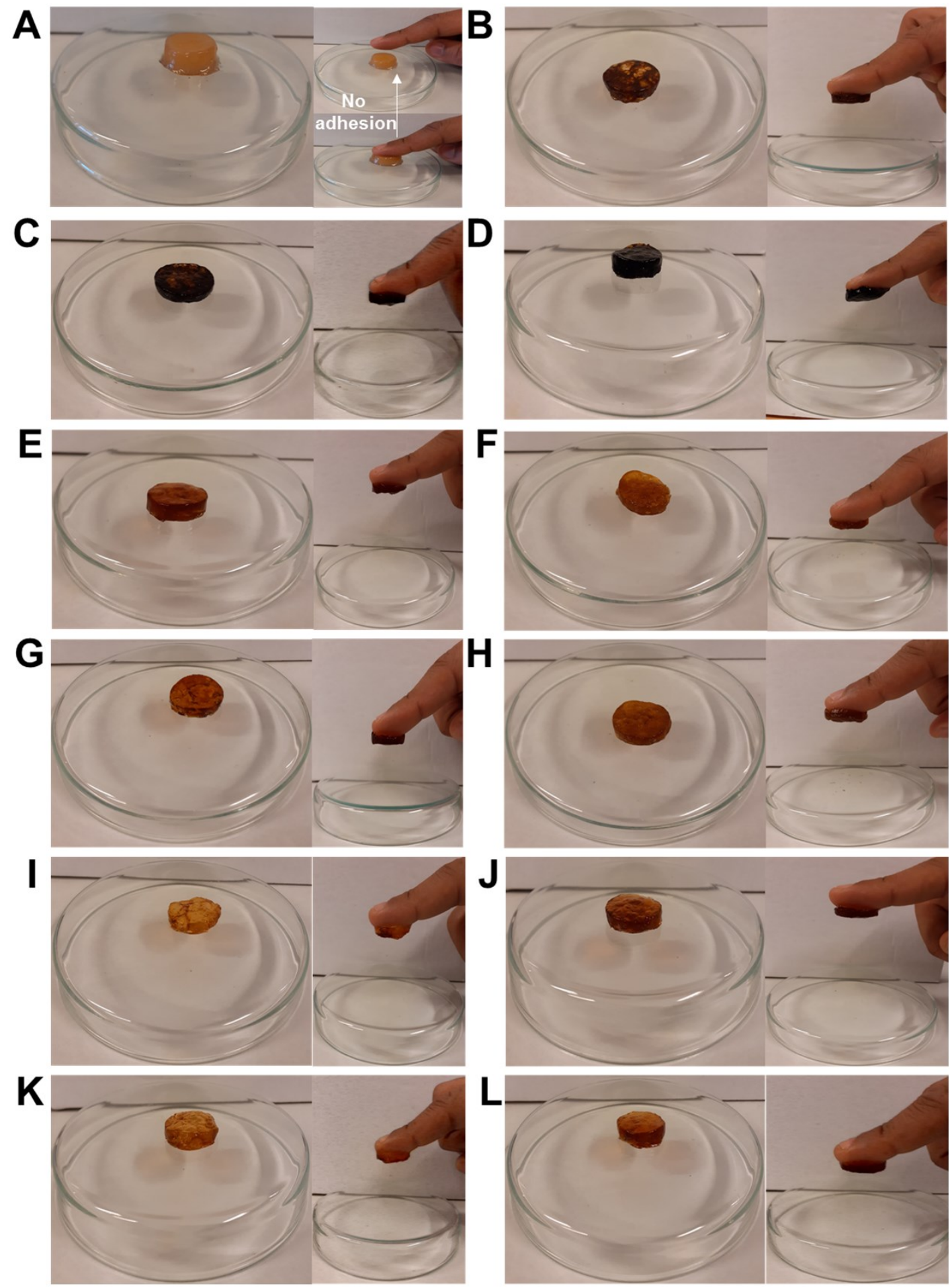

Figure S3. Images of the screening studies (from Figure 2A and Table S1) for engineering the lignin-based, crosslinked, tissue adhesive hydrogel, demonstrating the success of the crosslinking through the generation of self-standing hydrogels. Their initial tissue adhesion properties were evaluated by placing the researcher's finger onto the gel. Images corresponding to Figure 2A: (A) entry 5 and (B) entry 10. Images corresponding to Table S1: (C) entry 3, (D) entry 4, (E) entry 7, (F) entry 8, (G) entry 11, (H) entry 12, (I) entry 15, (J) entry 16, (K) entry 19 and (L) entry 20. 

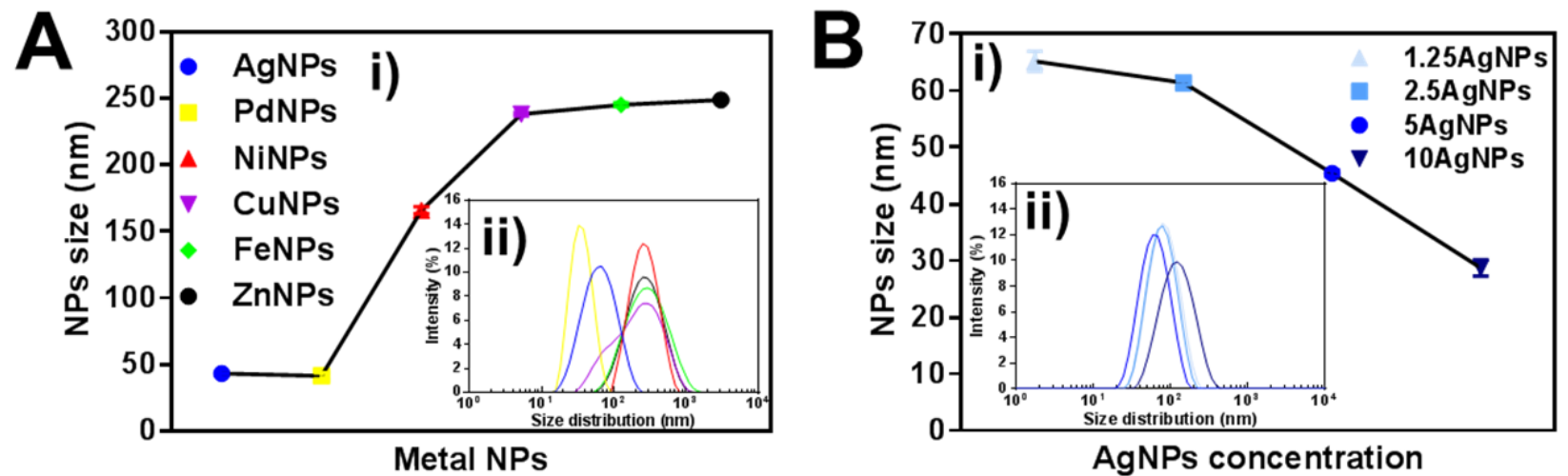

Figure S4. (A) i) The preparation of various Lignin metal nanoparticles (NPs) and the NPs sizes; ii) the size distribution. The concentration of the metal NPs was $5 \mathrm{mg} / \mathrm{mL}$. (B) i) The employment of various concentrations of silver and the impact of this on the NPs size; ii) the size distribution.

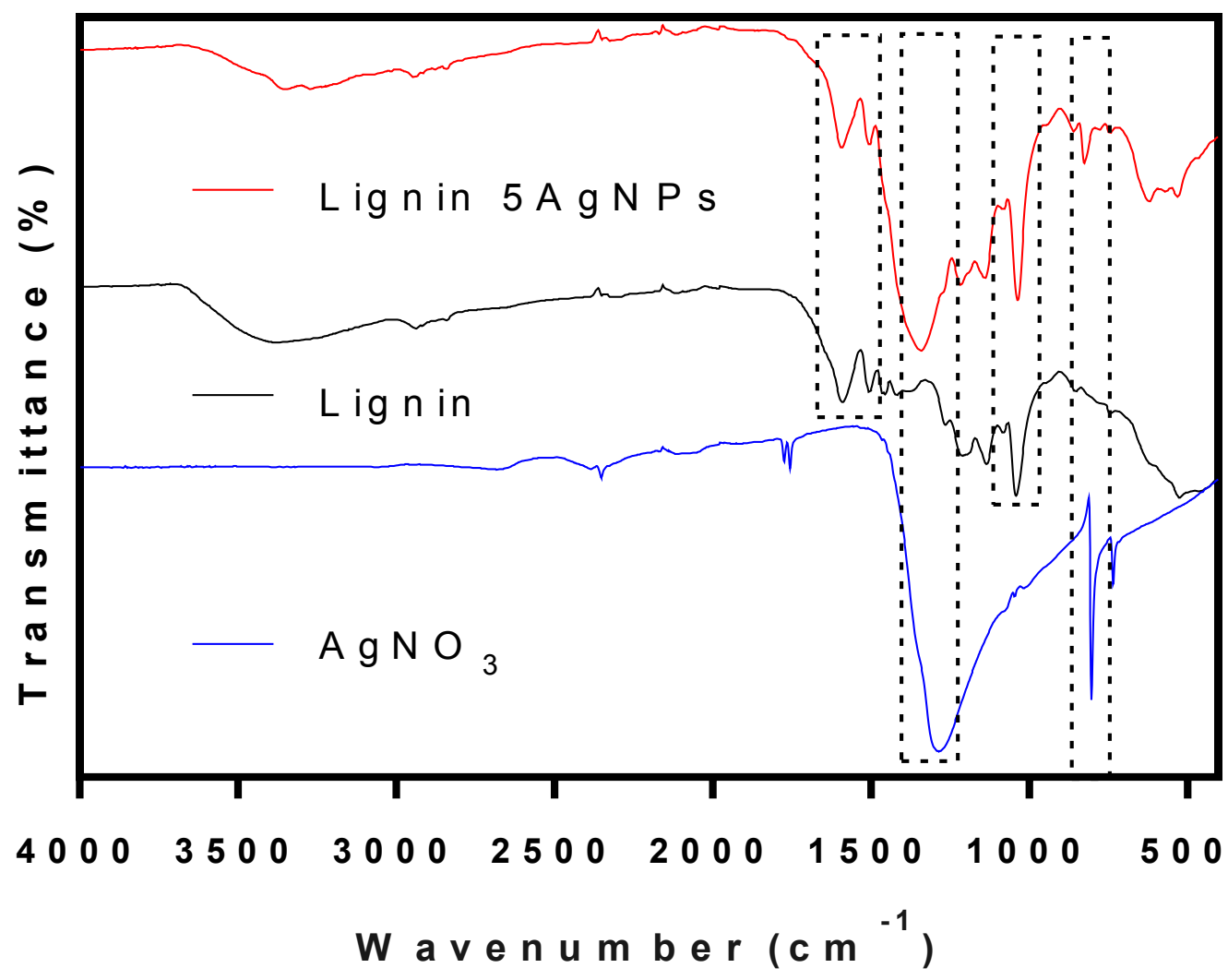

Figure S5. Fourier Transform Infrared spectroscopy (FTIR) of the Lignin 5AgNPs, lignin and $\mathrm{AgNO}_{3}$ samples. NPs = nanoparticles. 


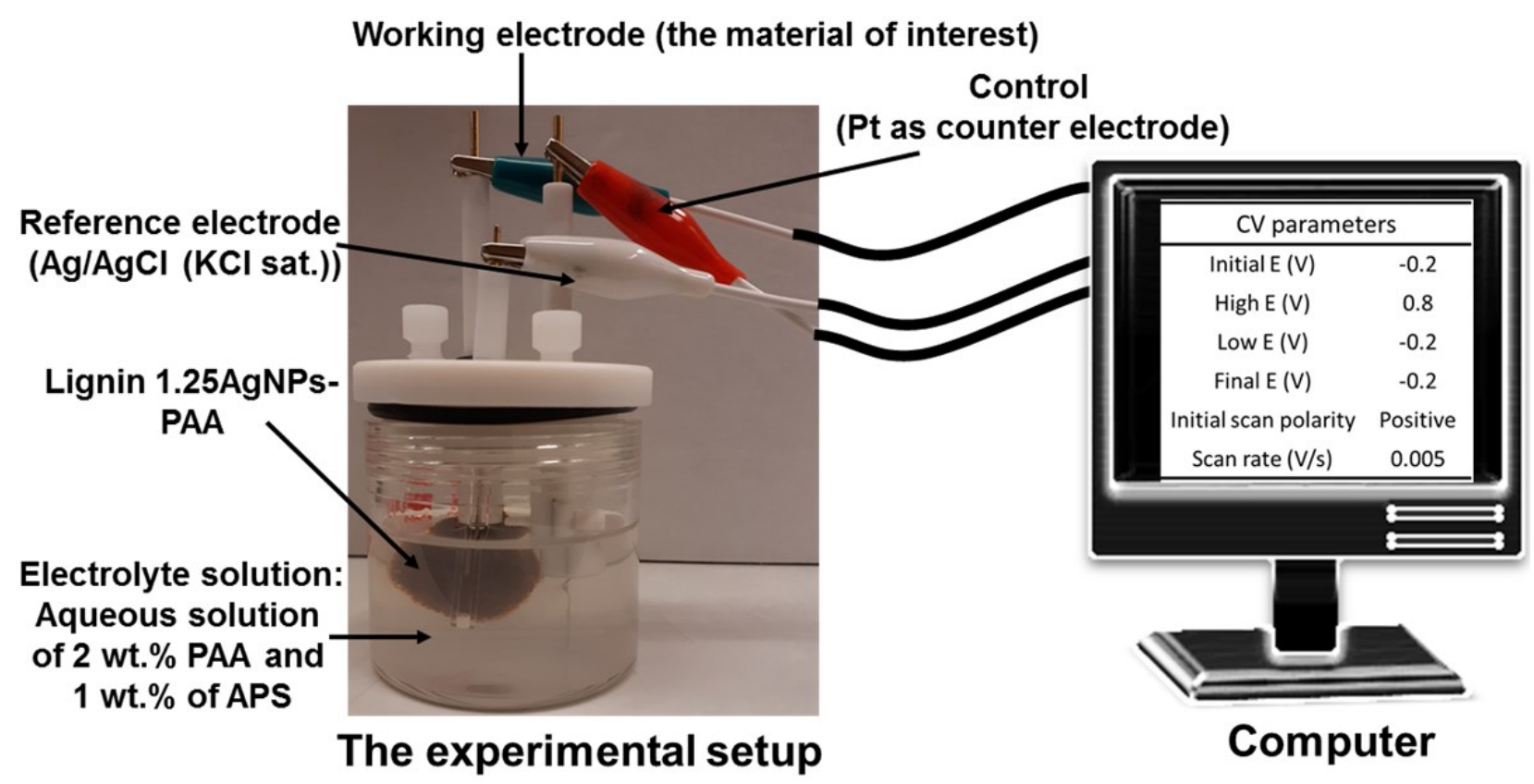

Figure S6. The experimental setup and parameters used for the electrochemical cell in cyclic voltammetry (CV) experiments.
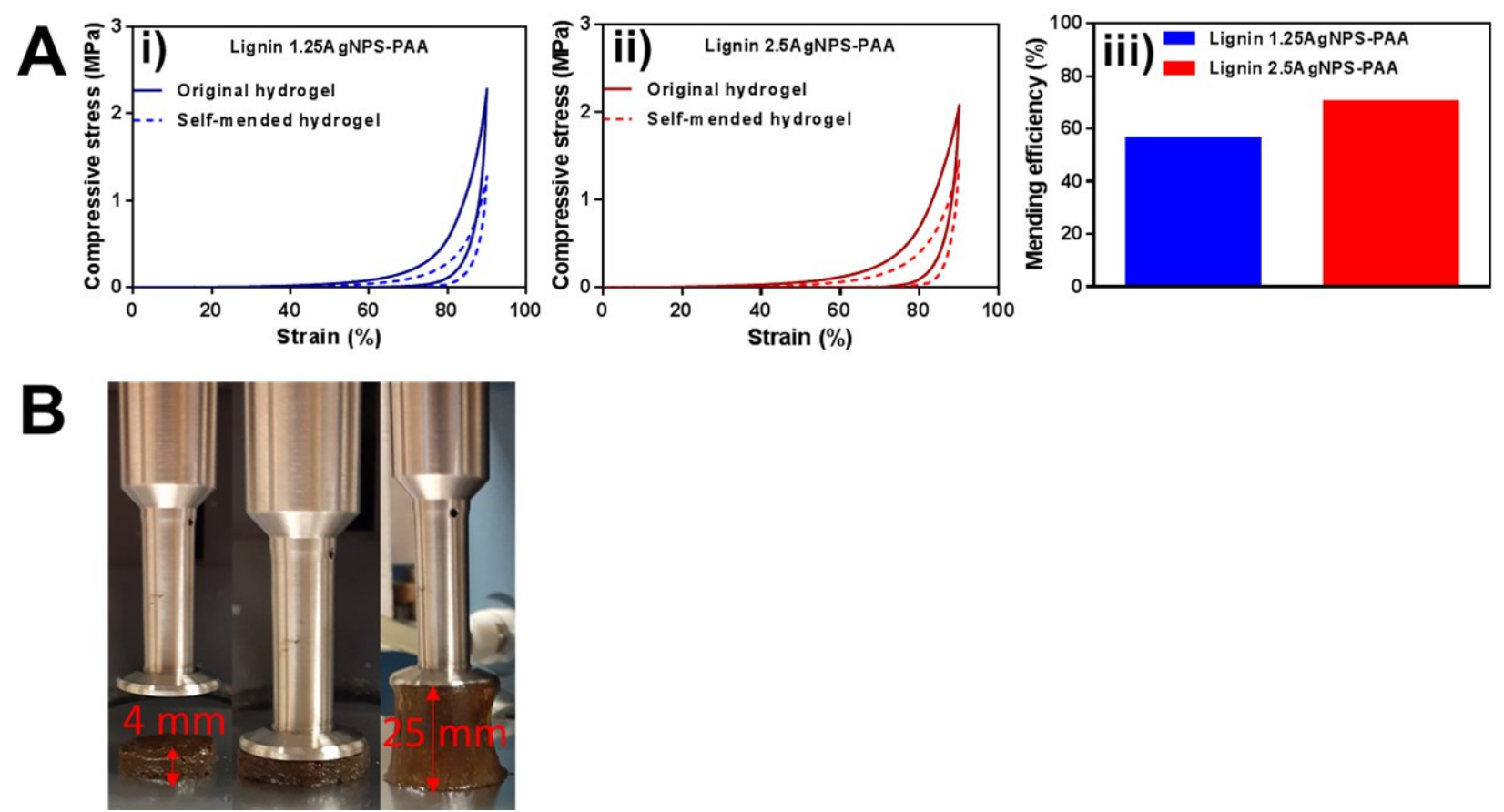

Figure S7. Experiments for the quantification of the self-mending efficiency and image demonstrating the elasticity of the hydrogels. (A) i)-iii) The mechanical evaluation and quantification of the self-mended hydrogels. (B) Experiment demonstrating the elasticity of the engineered hydrogel. The hydrogel was compressed at $37^{\circ} \mathrm{C}$ for 5 minutes and then pulled apart. 
A

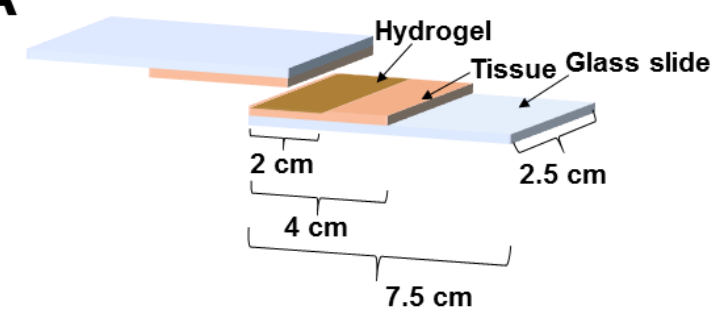

C

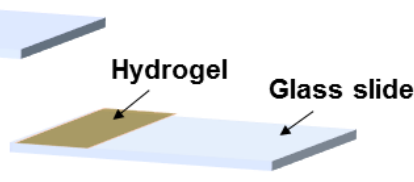

B Force

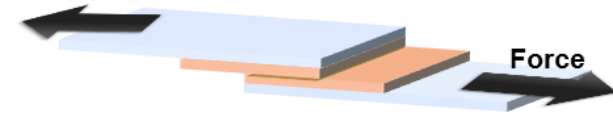

D

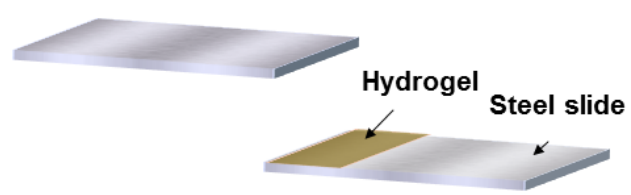

Figure S8. Illustration of the test setup to measure the adhesion of the hydrogels onto various surfaces. (A, B) Lap shear test employed to investigate the strength of adhesion to porcine skin and steel, using (C) glass slides or (D) steel slides.

A

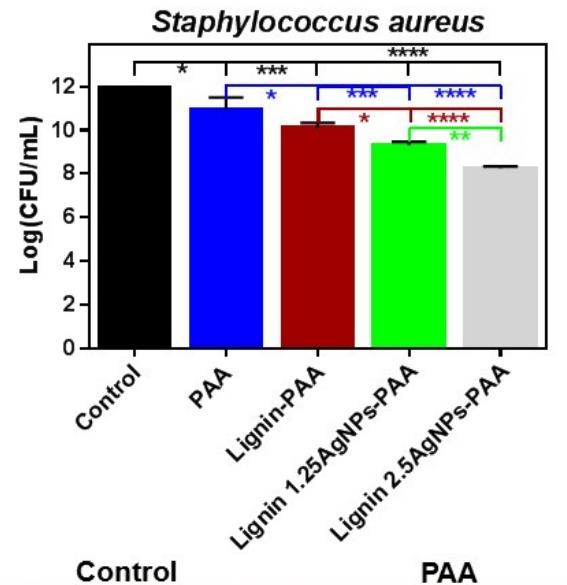

B

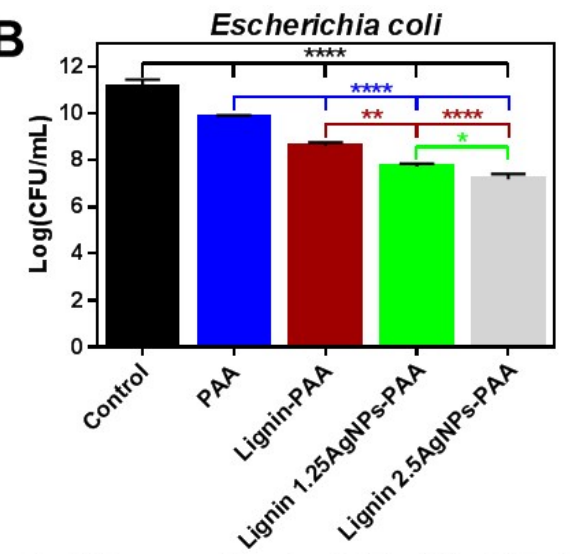

Lignin-PAA
Lignin 1.25AgNPs-PAA Lignin 2.5AgNPs-PAA

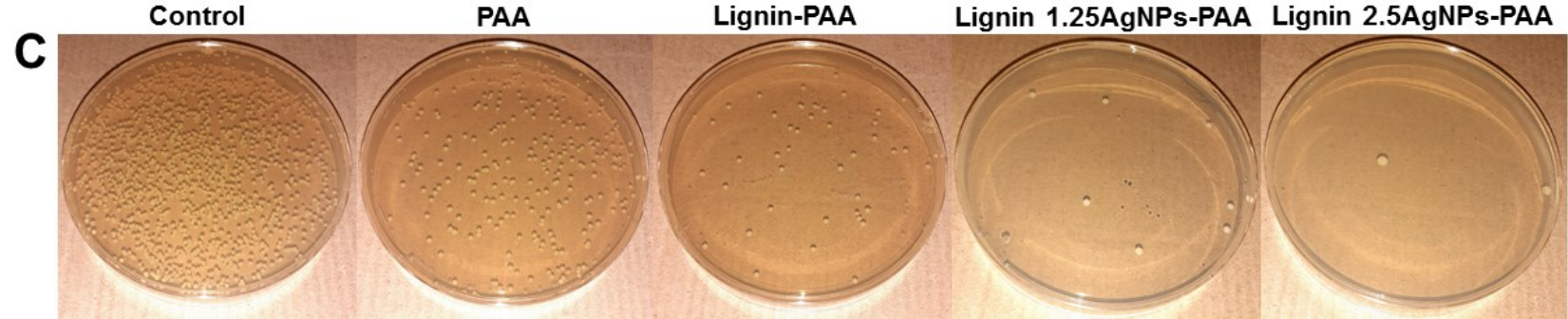

Figure S9. The antibacterial activity of the engineered hydrogels against Staphylococcus aureus (S. aureus) and Escherichia coli (E. Coli) in the elution experiments. The gels were incubated at $37{ }^{\circ} \mathrm{C}$ for $24 \mathrm{~h}$ in BHI Broth. After their removal, the antibacterial activity of the solution was measured. The figures shows the colony-forming units (CFUs) of (A) S. aureus and (B) E. Coli after $24 \mathrm{~h}$ incubation with the various solutions. Values are means $\pm S D$, generated by one-way ANOVA followed by Tukey's multiple comparison test; $\left.\left.\left.N=3 .{ }^{*}\right) \mathrm{p}<0.05,\left({ }^{* *}\right) \mathrm{p}<0.01,{ }^{* * *}\right) \mathrm{p}<0.005,{ }^{* * * *}\right) \mathrm{p}<0.001$, indicating statistically significant differences. (C) Selected images of the $S$. aureus colonies on agar plates from diluted bacterial suspensions of the various hydrogels and a control. NPs = nanoparticles; PAA = polyacrylic acid. 

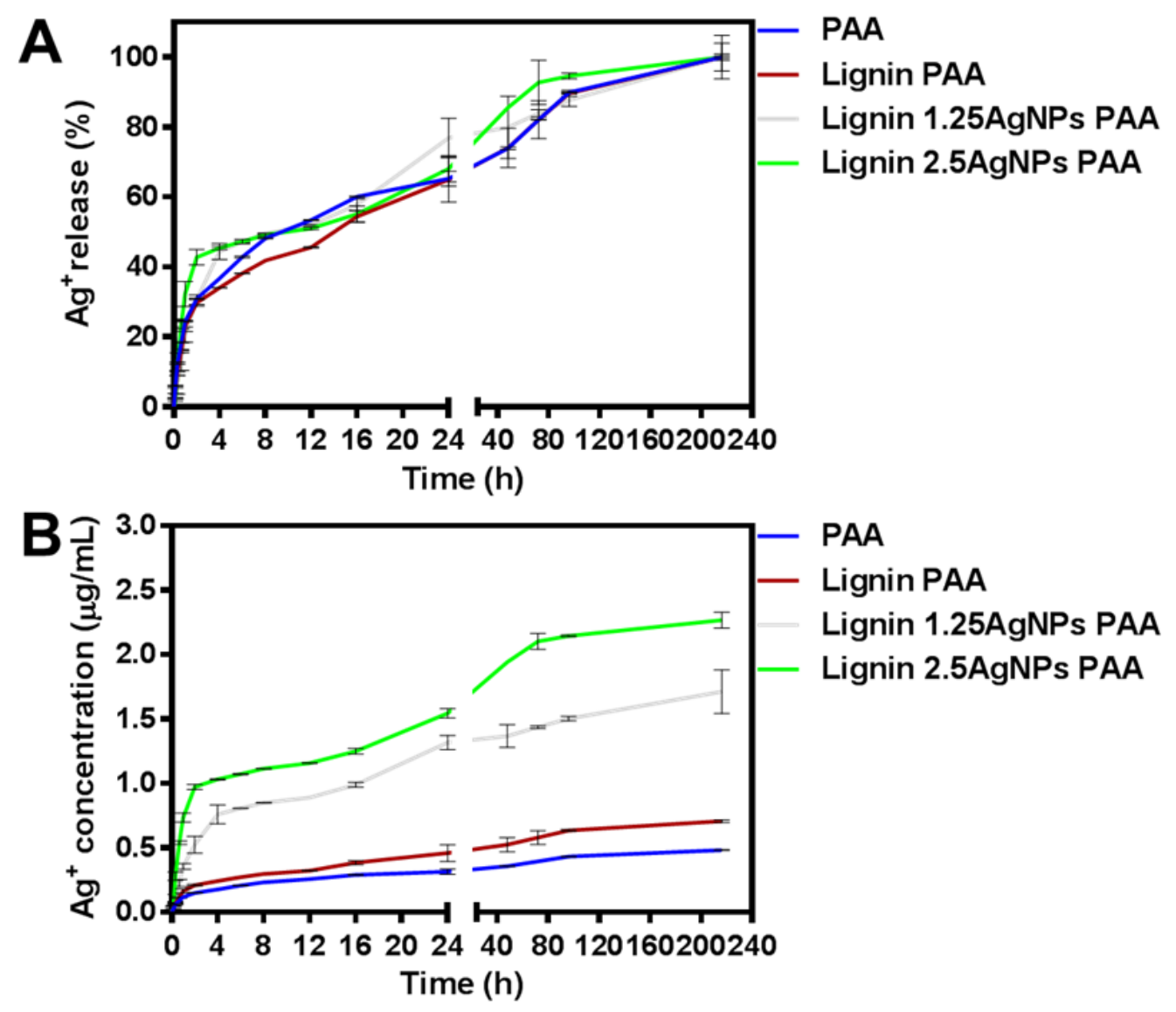

Figure S10. The $\mathrm{Ag}^{+}$release profile from the engineered hydrogels presented as (A) \%-released and (B) concentration $(\mu \mathrm{g} / \mathrm{mL})$ released over 9 days. The data are represented as means $\pm \mathrm{SD} ; N=3$. NPs = nanoparticles; $\mathrm{PAA}=$ polyacrylic acid .
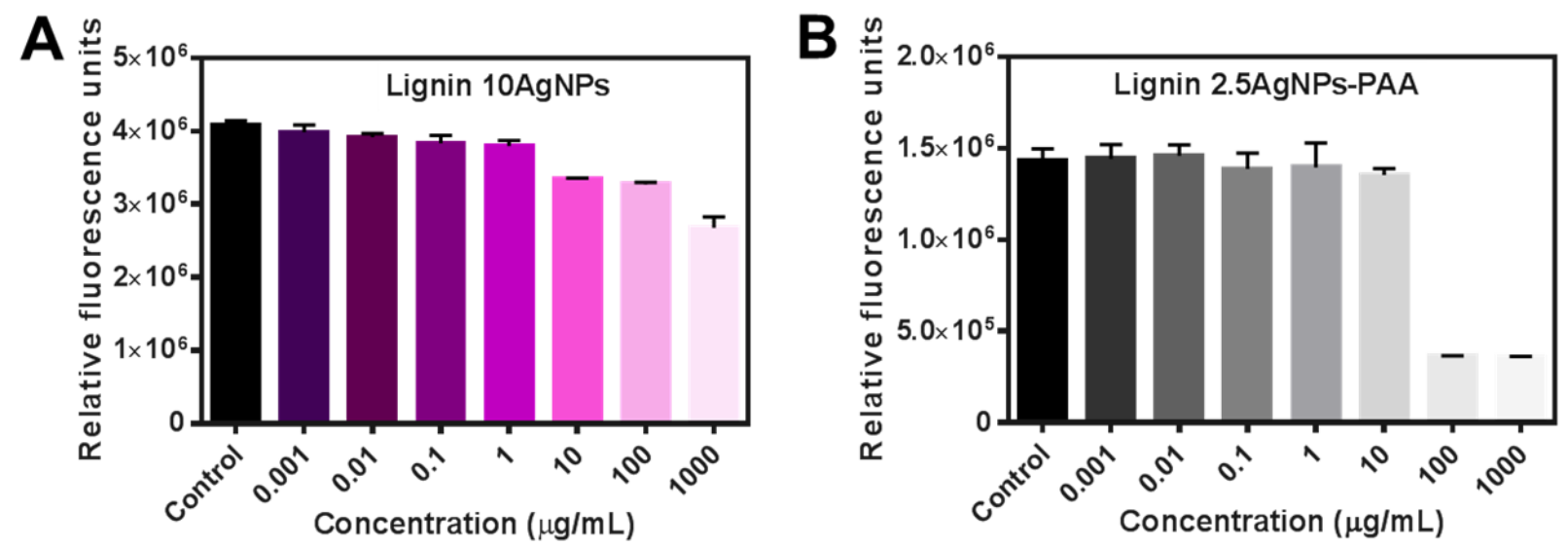

Figure S11. The cytotoxicity of the various compositions was determined using NIH 3T3 fibroblasts, with $48 \mathrm{~h}$ of incubation on increasing sample concentrations (0.001 to $1000 \mu \mathrm{g} / \mathrm{mL})$. The figure shows the cell viability of the (A) Lignin 10AgNPs and (B) Lignin 2.5AgNPs-PAA samples. The data are represented as means \pm SD; $N=5$. NPs = nanoparticles; PAA = polyacrylic acid . 


\section{References}

(1) Dawes, G. J. S.; Scott, E. L.; Le Nôtre, J.; Sanders, J. P.; Bitter, J. H., Deoxygenation of Biobased Molecules by Decarboxylation and Decarbonylation-A Review on the Role of Heterogeneous, Homogeneous and Bio-Catalysis. Green Chem. 2015, 17, 3231-3250.

(2) Wu, G.; Lin, S.; Yang, C., Preparation and Characterization of PVA/PAA Membranes for Solid Polymer Electrolytes. J. Membr. Sci. 2006, 275, 127-133.

(3) Khanlari, S.; Dubé, M. A., Effect of pH on Poly (acrylic Acid) Solution Polymerization. J. Macromol. Sci., Part A 2015, 52, 587-592.

(4) Weng, G.; Huang, Y.; Thanneeru, S.; Li, H.; Alamri, A.; He, J., Cross-Linking of COOH-Containing Polymers Using Ag (I)-Catalyzed Oxidative Decarboxylation in Aqueous Solution. Soft Matter 2017, 13 (29), 5028-5037.

(5) Anderson, J. M.; Kochi, J. K., Silver(I)-Catalyzed Oxidative Decarboxylation of Acids by Peroxydisulfate. Role of Silver(II). J. Am. Chem. Soc. 1970, 92, 1651-1659.

(6) Fristad, W. E.; Klang, J. A., Silver (I)/Persulfate Oxidative Decarboxylation of Carboxylic Acids. Arylacetic Acid Dimerization. Tetrahedron Lett. 1983, 24, 2219-2222. 